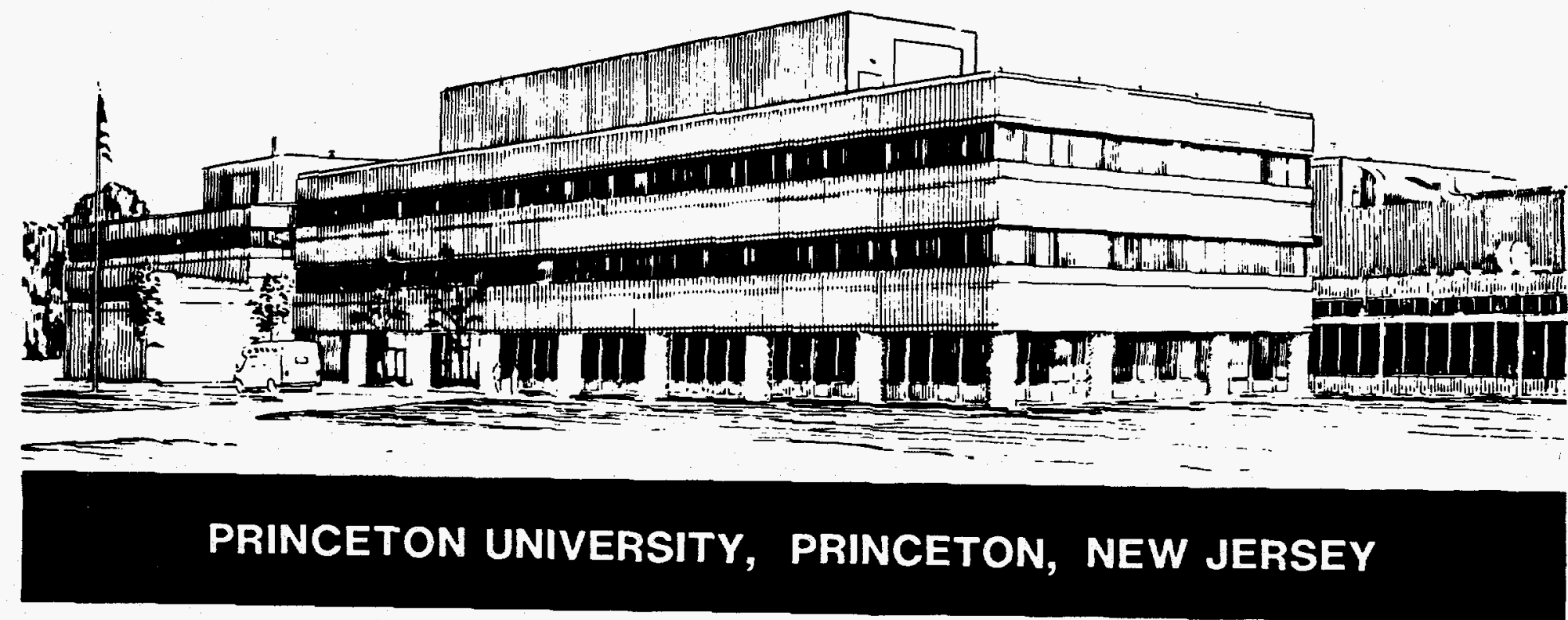




\section{NOTICE}

This report was prepared as an account of work sponsored by an agency of the United States Government. Neither the United States Government nor any agency thereof, nor any of their employees, makes any warranty, express or implied, or assumes any legal liability or responsibility for the accuracy, completeness, or usefulness of any information, apparatus, product, or process disclosed, or represents that its use would not infringe privately owned rights. Reference herein to any specific commercial produce, process, or service by trade name, trademark, manufacturer, or otherwise, does not necessarily constitute or imply its endorsement, recommendation, or favoring by the United States Government or any agency thereof. The views and opinions of authors expressed herein do not necessarily state or reflect those of the United States Government or any agency thereof.

\section{NOTICE}

This report has been reproduced from the best available copy.

Available in paper copy and microfiche.

Number of pages in this report: 8

DOE and DOE contractors can obtain copies of this report from:

Office of Scientific and Technical Information

P.O. Box 62

Oak Ridge, TN 37831;

(615) $576-8401$.

This report is publicly available from the:

National Technical Information Service

Department of Commerce

5285 Port Royal Road

Springfield, Virginia 22161

(703) $487-4650$ 


\section{DISCLAIMER}

Portions of this document may be illegible in electronic image products. Images are produced from the best available original document. 


\title{
Supershot Performance with Reverse Magnetic Shear in TFTR
}

\author{
S. H. Batha, , ${ }^{\text {) }}$ F. M. Levinton, a) M. C. Zarnstorff, b) and G. L. Schmidt ${ }^{\text {b) }}$
}

a) Fusion Physics and Technology, Inc., Torrance, CA USA 90503

b)Princeton Plasma Physics Laboratory, P.O. Box 451, Princeton, NJ USA 08543

\begin{abstract}
Discharges with large regions of reversed magnetic shear and good energy and particle confinement have been produced in the Tokamak Fusion Test Reactor. These plasmas were created by heating the plasma during a rapid plasma current increase. The stability of these discharges is dependent on the shape of the q profile, in particular the value and location of the minimum value of q. Control of the q profile by optimizing the plasma startup, prelude start time, the neutral-beam directionality during the prelude heating phase, and the plasma current ramp rate is demonstrated. High-performance discharges, created by injecting more than 18 to $25 \mathrm{MW}$ of neutral beam power into a plasma with reverse shear, are also described.
\end{abstract}

DISTRIBUTION OF THIS DOCUMENT IS UNLIMITED

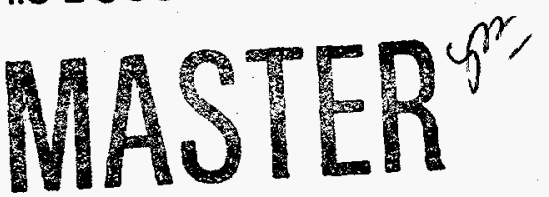




\title{
Supershot Performance with Reverse Magnetic Shear in TFTR
}

\author{
S. H. Batha, a) F. M. Levinton, a) M. C. Zarnstorff, b) and G. L. Schmidtb)
}

a)Fusion Physics and Technology, Inc., Torrance, CA USA 90503

b)Princeton Plasma Physics Laboratory, P.O. Box 451, Princeton, NJ USA 08543

\section{Introduction}

Discharges with large regions of reversed magnetic shear and good energy and particle confinement have been produced in the Tokamak Fusion Test Reactor (TFTR).[1] Negative magnetic shear has been predicted to improve transport by stabilizing some classes of magnetohydrodynamic instabilities such as ballooning and resistive tearing modes, and also some microinstabilities. It is also desirable for good bootstrap current alignment. The stability is dependent upon $\mathrm{q}(0)$, the minimum value of $\mathrm{q}\left(\mathrm{q}_{\min }\right)$, and the location of the $\mathrm{q}_{\min }$ surface [normalized minor radius ( $\mathrm{r} / \mathrm{a})_{\mathrm{qmin}}$ or major radius $\mathrm{R}_{\mathrm{qmin}}$ ], as well other parameters which are as yet unknown. Several techniques have been developed to control the q profile on TFTR and are described in section 2. High-performance discharges are created by injecting more than 18 to $25 \mathrm{MW}$ of neutral beam power into a reversed-shear target plasma. Such a discharge is described in section 3.

Heating of the plasma during a rapid plasma current increase is necessary to produce a reversed-shear current profile. Heating raises the plasma temperature which increases the current diffusion time and slows penetration of the plasma current to the center of the plasma. The most efficient method is to start the heating as early as possible during a "prelude" phase during the initial current ramp. The current ramp alone is insufficient, as shown in Fig. 1.

The prelude heating can be from tangential neutral beams (NB), as shown in Fig. 2(c), or from ICRF. The preferred "prelude" phase of the discharge has $\mathrm{P}_{\mathrm{nb}}=5 \mathrm{MW}$ beginning at about $0.55 \mathrm{sec}$ and increasing to $8 \mathrm{MW}$ at $1.0 \mathrm{sec}$ with $P_{c o}=6 \mathrm{MW}$ and $P_{c t r}=2 \mathrm{MW}$. The plasma current rises at a rate of $1.6 \mathrm{MA} / \mathrm{sec}$ for the first half second. The ramp rate is then decreased to $0.4 \mathrm{MA} / \mathrm{sec}$ until the desired plasma current of 1.6 MA is reached at $2.0 \mathrm{sec}$. The plasma major radius is approximately the final value of $2.60 \mathrm{~m}$ at $0.1 \mathrm{sec}$. The toroidal field reaches its full value of $4.6 \mathrm{~T}$ at $2.60 \mathrm{~m}$ at $0.0 \mathrm{sec}$.

Profiles of the magnetic-field pitch angles in

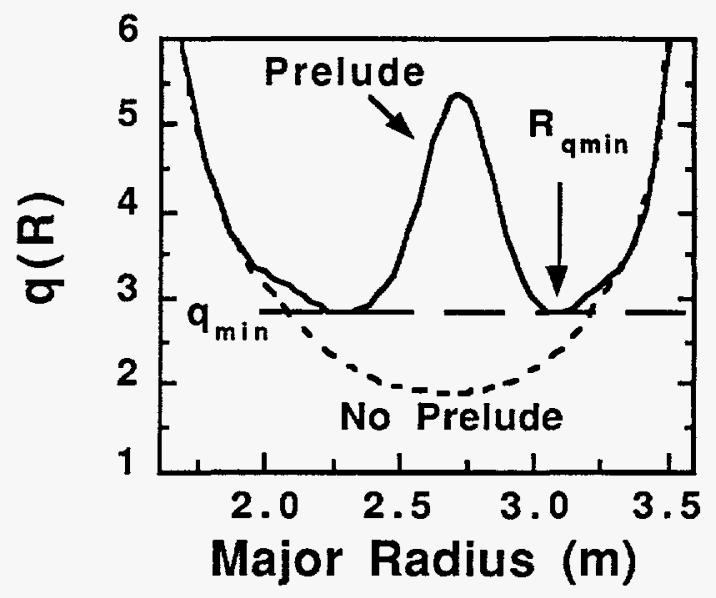

Fig. 1: The measured $q$ profile at 2.55 sec for discharges with and without prelude heating. 
TFTR are measured by a motional-Stark-effect polarimeter with good spatial and temporal resolution.[2] The equilibria are then reconstructed with the VMEC free-boundary equilibrium code[3] which determines the values of $q_{\min }$ and $(r / a)_{q m i n}$ with accuracies of $10 \%$ and $5 \%$, respectively.

\section{2. q-Profile Control}

Control of the $q$ profile has been achieved by optimizing the plasma startup, prelude start time, the NB directionality during the prelude heating phase, and the plasma current ramp rate. It has been observed that high levels of MHD activity during the prelude phase can lead to very rapid current penetration even with early neutral-beam injection. The resulting plasmas have lower values of $q(0)$ and no regions of reverse shear. Details of the plasma startup such as current ramp rate, time at which the current ramp rate changes, major radius evolution, and value of $q(a)$, have been optimized to avoid such MHD.

Shear reversal over half the plasma minor radius at the start of the heating phase has been obtained by very early beam injection as shown in Fig. 3. Delaying the prelude heating decreases the size of the reverse shear region. The value of $q_{\min }$ also decreases at $2.55 \mathrm{sec}$ (the start of the high-power phase) from $q_{\min }=$ 2.8 to 2.0 as the prelude start time is delayed from 0.55 to $1.5 \mathrm{sec}$. Also, $\mathrm{q}(0)$ decreases from about 6 to about 2 . The prelude start time has little affect on the rate at which the shear reversal region shrinks or $\mathrm{q}_{\min }$ decreases. Further control of $(\mathrm{r} / \mathrm{a})_{\mathrm{qmin}}$ and $\mathrm{q}_{\min }$ can be achieved by varying the start time of the high-power heating phase, as shown in Fig. 2 .

The $\mathrm{q}$ profile is also affected by the direction of the injected neutral-beam power during the prelude. For example, unidirectional NB injection would lead to strong beam-driven

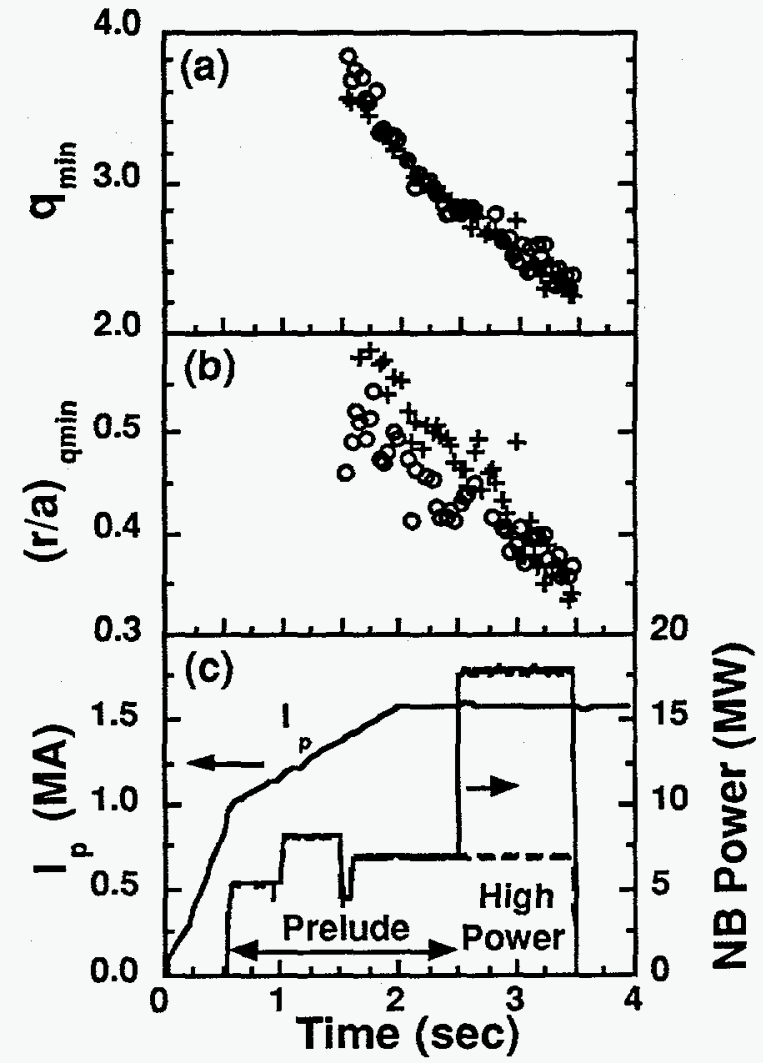

Fig. 2: qmin (a) and (ria) qmin (b) for discharges with (o) and without $(+)$ a high-power phase starting at $2.5 \mathrm{sec}$. The plasma current and neutral-beam heating waveforms are shown in (c).

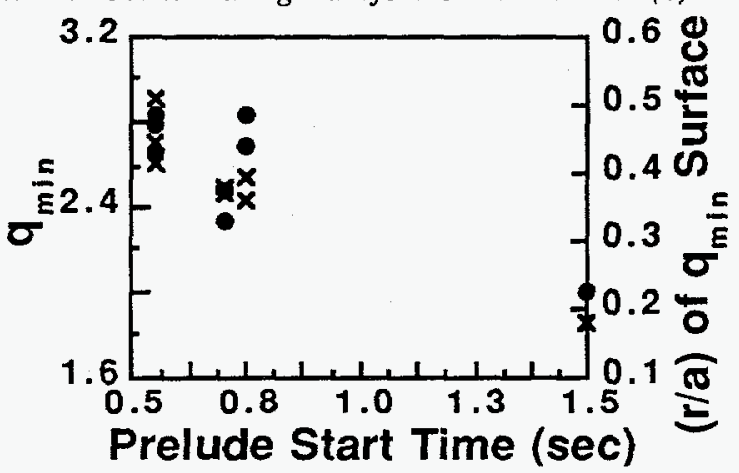

Fig. 3: Delaying the prelude heating start time decreases $q_{\min }(\cdot)$ and the size of the region with reverse shear $(x)$ at the start of the high-power heating phase. 
currents while injection with equal amounts of power in the direction of the plasma current (co-injection) and counter to the plasma current (ctr-injection) would minimize the beam-driven current. Experiments which varied the amount of co- and ctr-injected power during the prelude phase are shown in Fig. 4. The largest values of $(\mathrm{r} / \mathrm{a})_{\mathrm{qmin}}$ are created by predominantly co-injection. However, co-only injection of $8 \mathrm{MW}$ during the prelude caused the discharge to disrupt. It is not yet clear

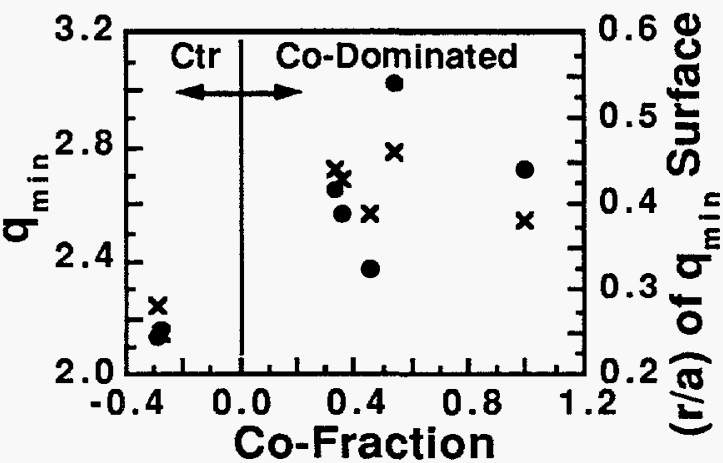

Fig. 4: Co-dominated $N B$ injection during the prelude phase increases $q_{\min }(\cdot)$ and the region of reverse shear $(X)$. Co-Fraction is defined as $\left(P_{c o}-P_{c t r}\right) / P_{n b}$ whether pure co-injection of less than $8 \mathrm{MW}$ raises $\mathrm{q}_{\min }$ more than does a co-fraction of $\approx$ 0.5 .

Increasing the current ramp rate from the nominal $0.4 \mathrm{MA} / \mathrm{sec}$ after $0.5 \mathrm{sec}$ modified the $\mathrm{q}$ profile and its evolution. Discharges with faster ramp rates reached the final current earlier in time than $2.0 \mathrm{sec}$. Comparisons at $0.16 \mathrm{sec}$ after a plasma current of $1.6 \mathrm{MA}$ was reached showed that a $20 \%$ faster ramp rate increased both the size of the reverse shear region and $q_{\min }$. Both quantities were reduced at the fixed time of $2.55 \mathrm{sec}$, however. Because $q_{\min }$ and $(\mathrm{r} / \mathrm{a})_{\text {qmin }}$ decrease at a predictable and reproducible rate during the discharge, a range of values can be accessed by varying the time of high-power injection.

Figure 5 displays the wide range of $\mathrm{q}$ profiles, as parameterized by $\mathrm{q}_{\min }$ and $(\mathrm{r} / \mathrm{a})_{\mathrm{qmin}}$, produced during the high-power phase of reversed-shear discharges through the techniques described here. Modest independent control of $(\mathrm{r} / \mathrm{a})_{\mathrm{qmin}}$ and of $\mathrm{q}_{\mathrm{min}}$ has been demonstrated. During the discharge, lower values of $\mathrm{q}_{\mathrm{min}}$ and $(\mathrm{r} / \mathrm{a})_{\mathrm{qmin}}$ are reached since both quantities continue to fall during a discharge. Future experiments are intended to develop methods that change the relationship between these quantities and to create larger regions of reversed shear with controlled values of $\mathrm{q}_{\min }$. Raising the plasma current from 1.6 MA, increasing the plasma current ramp rate, and beginning beam injection as early as $0.3 \mathrm{sec}$ will be explored. It will also be important to develop techniques such as mode-conversion current drive (MCCD)[4] or lower-hybrid current drive (LHCD) to hold $\mathrm{q}_{\min }$ and (r/a) qmin

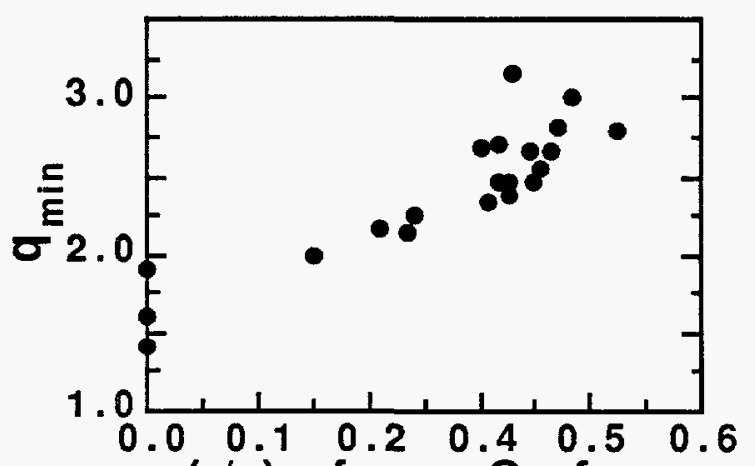

( $r / a)$ of $q_{\min }$ Surface

Fig. 5: The q profile control techniques described in this paper have accessed these q profiles. Data is shown at the start of the high-power phase. constant during a discharge. 


\section{High Performance}

High performance discharges were created by injecting up to $25 \mathrm{MW}$ of NB power when the values of $q_{\min }$ and $(r / a)_{q m i n}$ reached the desired values, typically at $2.5 \mathrm{sec}$. The values of $\mathrm{q}(0), \mathrm{q}_{\min }$ and $(\mathrm{r} / \mathrm{a})_{\mathrm{qmin}}$ decreased during the discharge at a predictable rate, Fig. 2. Highpower injection did not strongly affect the evolution of any of these quantities.

When an observed $P_{n b}$ threshold of 18 to 25

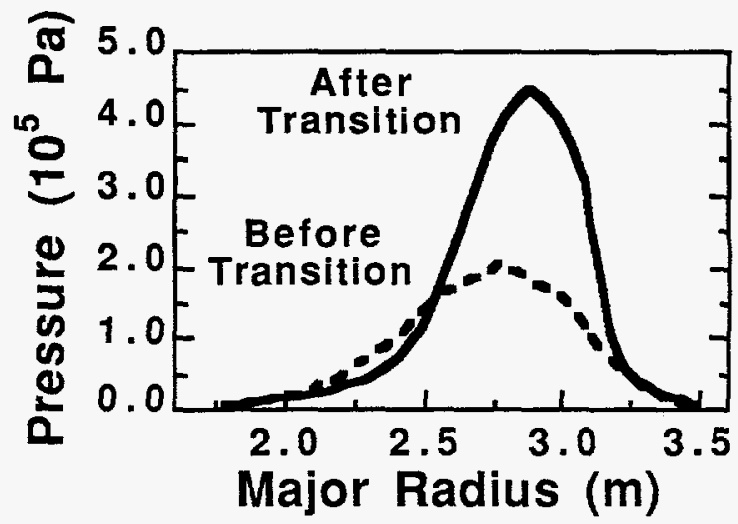

Fig. 6: The pressure at the center of the plasma is greatly increased when the discharge enters the $R / S$ mode. MW was surpassed, the discharge entered the reversed shear confinement mode ( $\mathrm{R} / \mathrm{S}$ mode) with drastically reduced particle and energy transport in the core of the plasma.[1] Figure 6 shows that the pressure in the center of the plasma was like that of a typical TFTR supershot before the R/S transition occurred during the high-power phase. After the transition, the pressure and pressure peaking factor $[p(0) /<p>]$ increased greatly. The increased central pressure reflects an increased central particle density caused by a dramatic decrease in both the electron and ion particle diffusivity. The global energy confinement time also increased

The plasma performance of the reverse shear plasma during the prelude phase was already similar to that of the supershot mode. Both have high electron and ion temperatures, high ratio of $T_{i} / T_{e}$, peaked density profiles, and energy confinement enhancement greater than 2 compared to L-mode scaling. When the plasma made the transition into the $R / S$ mode, performance was further improved.

Most of the discharges reaching the $\mathrm{R} / \mathrm{S}$ mode have disrupted due to $\mathrm{MHD}$ instabilities. The driving mechanism has not yet been determined unequivocally. However, the MHD activity was only observed outside (r/a) qmin which is significantly outside the location of the peak pressure gradient. There was no activity observed in the core of the plasma. In contrast, the disruption stability of standard TFTR supershots is limited by MHD instabilities in the plasma core at the peak of the pressure gradient.

This work was supported by the U. S. Department of Energy Contract No. DE-AC02-76CHO-3073.

\section{References}

1. F. M. Levinton et al., submitted to Phys. Rev. Lett. (1995).

2. F. M. Levinton et al., Phys. Fluids B 5, 2554 (1993).

3. S. P. Hirshman et al., Phys. Plasmas 1, 2277 (1994).

4. R. Majeski et al., to be published in Phys. Rev. Lett. (1995). 
Dr. F. Paoloni, Univ. of Wollongong, AUSTRALIA

Prot. R.C. Cross, Univ. of Sydney, AUSTRALIA

Plasma Research Lab., Australian Nat. Univ., AUSTRALIA

Prof. I.R. Jones, Flinders Univ, AUSTRALIA

Prof. F. Cap, Inst. for Theoretical Physics, AUSTRIA

Prof. M. Heindler, Institut tür Theoretische Physik, AUSTRIA

Prof. M. Goossens, Astronomisch instituut, BELGIUM

Ecole Royale Militaire, Lab. de Phy. Plasmas, BELGIUM

Commission-European, DG. XII-Fusion Prog., BELGIUM

Prof. R. Bouciqué, Rijksuniversiteit Gent, BELGIUM

Dr. P.H. Sakanaka, Instituto Fisica, BRAZIL.

Prof. Dr. I.C. Nascimento, Instituto Fisica, Sao Paulo, BRAZIL Instituto Nacional De Pesquisas Espaciais-INPE, BRAZIL

Documents Office, Atomic Energy of Canada Ltd., CANADA

Ms. M. Morin, CCFWTokamak de Varennes, CANADA

Dr. M.P. Bachynski, MPB Technologies, Inc., CANADA

Dr. H.M. Skarsgard, Univ. of Saskatchewan, CANADA

Prof. J. Teichmann, Univ. of Montreal, CANADA

Prof. S.R. Sreenivasan, Univ. of Calgary, CANADA

Prof. R. Marchand, INRS-Energie et Materiaux, CANADA

Dr. R. Bolton, Centre canadien de fusion magnétique, CANADA

Dr. C.R. James, Univ. of Alberta, CANADA

Dr. P. Lukác, Komenského Universzita, CZECHO-SLOVAKIA

The Librarian, Culham Laboratory, ENGLAND

Library, R61, Rutherford Appleton Laboratory, ENGLAND

Mrs. S.A. Hutchinson, JET Library, ENGLAND

Dr. S.C. Sharma, Univ. of South Pacific, FIJI ISLANDS

P. Mähönen, Univ. of Helsinki, FINLAND

Prof. M.N. Bussac, Ecole Polytechnique,, FRANCE

C. Mouttet, Lab. de Physique des Milieux lonisés, FRANCE

J. Radet, CEN/CADARACHE - Bat 506, FRANCE

Prof. E. Economou, Univ. of Crete, GREECE

Ms. C. Rinni, Univ. of loannina, GREECE

Preprint Library, Hungarian Academy of Sci., HUNGARY

Dr. B. DasGupta, Saha Inst. of Nuclear Physics, INDIA

Dr. P. Kaw, Inst. for Plasma Research, INDIA

Dr. P. Rosenau, Israel Inst. of Technology, ISRAEL.

Librarian, Intemational Center for Theo Physics, ITALY

Miss C. De Palo, Associazione EURATOM-ENEA , ITALY

Dr. G. Grosso, Istituto di Fisica del Plasma, ITALY

Prof. G. Rostangni, Istituto Gas lonizzati Del Cnr, ITALY
Dr. H. Yamato, Toshiba Res \& Devel Center, JAPAN

Prof. I. Kawakami, Hiroshima Univ., JAPAN

Prof. K. Nishikawa, Hiroshima Univ., JAPAN

Librarian, Naka Fusion Research Establishment, JAERI, JAPAN

Director, Japan Atomic Energy Research Inst., JAPAN

Prof. S. Itoh, Kyushu Univ., JAPAN

Research Info. Ctr., National Instit. for Fusion Science, JAPAN

Prof. S. Tanaka, Kyoto Univ., JAPAN

Library, Kyoto Univ., JAPAN

Prot. N. Inoue, Univ. of Tokyo, JAPAN

Secretary, Plasma Section, Electrotechnical Lab., JAPAN

Dr. O. Mitarai, Kumamoto Inst. of Technology, JAPAN

Dr. G.S. Lee, Korea Basic Sci. Ctr., KOREA

J. Hyeon-Sook, Korea Atomic Energy Research Inst., KOREA

D.I. Choi, The Korea Adv. Inst. of Sci. \& Tech., KOREA

Leandro Melendez Lugo, Inst. Nac1. de Inves. NuCl, MEXICO

Prof. B.S. Liley, Univ. of Waikato, NEW ZEALAND

Inst of Physics, Chinese Acad Sci PEOPLE'S REP. OF CHINA

Library, Inst. of Plasma Physics, PEOPLE'S REP. OF CHINA

Tsinghua Univ. Library, PEOPLE'S REPUBLIC OF CHINA

Z. Li, S.W. Inst Physics, PEOPLE'S REPUBLIC OF CHINA

Prof. J.A.C. Cabral, Instituto Superior Tecnico, PORTUGAL

Prof. M.A. Hellberg, Univ. of Natal, S. AFRICA

Prof. D.E. Kim, Pohang Inst. of Sci. \& Tech., SO. KOREA

Prof. C.I.E.M.A.T, Fusion Division Library, SPAIN

Dr. L. Stentlo, Univ. of UMEA, SWEDEN

Library, Royal Inst. of Technology, SWEDEN

Prof. H. Withelmson, Chalmers Univ. of Tech., SWEDEN

Centre Phys. Des Plasmas, Ecole Polytech, SWITZERLAND

Bibliotheek, Inst. Voor Plasma-Fysica, THE NETHERLANDS

Asst. Prof. Dr. S. Cakir, Middle East Tech. Univ., TURKEY

Dr. V.A. Glukhikh,Sci. Res. Inst. Electrophys.I Apparatus, USSR

Dr. D.D. Ryutov, Siberian Branch of Academy of Sci., USSR

Dr. G.A. Eliseev, I.V. Kurchatov Inst., USSR

Librarian, The Ukr.SSR Academy of Sciences, USSR

Dr. L.M. Kovrizhnykh, Inst. of General Physics, USSR

Kemforschungsanlage GmbH, Zentralbibliothek, W. GERMANY

Bibliothek, inst. Für Plasmaforschung, W. GERMANY

Prof. K. Schindler, Ruhr-Universitát Bochum, W. GERMANY

Dr. F. Wagner, (ASDEX), Max-Planck-Institut, W. GERMANY

Librarian, Max-Planck-Institut, W. GERMANY 